\title{
Comunicação, poder e jornalismo - O quarto poder na era digital
}

institucionales.us.es/ambitos/

\section{Mirian Nogueira Tavares \\ Universidade do Algarve \\ mtavares@ualg.pt}

I hate television. I hate it as much as peanuts.

But I can't stop eating peanuts.

\section{Orson Welles}

Tornou-se lugar-comum falar do jornalismo como "o quarto poder", aquele que vem a seguir aos poderes estabelecidos pelo Estado: o legislativo, o executivo e o judiciário. A expressão, no entanto, data ainda do século XIX e consta que foi dita no

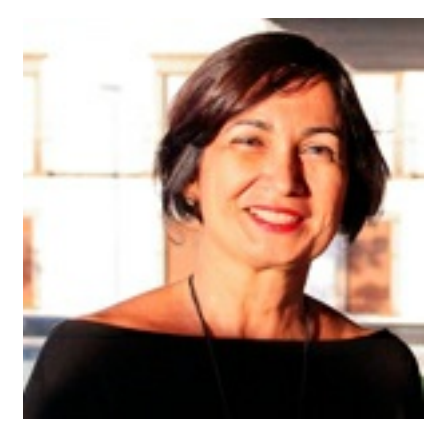
Parlamento inglês, por um deputado que, ao apontar à tribuna onde se encontravam os jornalistas, disse que eles eram "o quarto estado", aludindo aos 3 états da Revolução Francesa - o clero, a nobreza e a burguesia. No sentido moderno a ideia de jornalismo como "quarto poder" está intimamente vinculada à capacidade que o mesmo teria de construir, ou ajudar a fazê-lo, a própria realidade, ou seja, através das informações que estão (quase) sempre entre o público e o facto, há todo um processo que não se cinge apenas a transmissão ou difusão, mas que pode conter a efabulação, a encenação ou mesmo a montagem da realidade tal qual ela se apresenta.

Para muitos, os defensores da sacrossanta neutralidade jornalística, esta ideia construcionista é, não só pecaminosa, como pode ser fatal para a necessária liberdade de imprensa. Deontologicamente cabe aos jornalistas divulgar de forma clara e objetiva, sem ceder a ideologias pessoais ou coletivas, os eventos. Mas, sabemos que a subjetividade, intrínseca aos discursos, jamais desaparece e que em maior ou menor grau todo e qualquer discurso é atravessado pela opinião, o sentimento, as ideias e os temores daquele que fala. Mesmo que não seja de forma direta, o sujeito acaba por vir à tona através do estilo, dos temas que elege ou mesmo do veículo que utiliza para propagar a sua informação.

Se a neutralidade é um mito e se o jornalismo é, de facto, um poder, há que se ter um cuidado redobrado com o que lemos e há ainda que se formar jornalistas com sentido ético apurado e leitores capazes de verdadeiramente "ler" aquilo que se Ihes apresenta. Porque a leitura, quer de textos ou de imagens, exige de nós muito mais que saber interpretar signos e sinais, sobretudo na dita "era da informação" em que somos assoberbados de mensagens nos diversos canais que medeiam a nossa relação com o mundo. Não é por acaso que a literacia dos media se tornou um tema de vital importância no mundo, 
principalmente na Europa que, desde há algum tempo, busca criar espaços de discussão e projetos que promovam a literacia para todos como um bem fundamental dos cidadãos. Melhor dizendo, como um bem essencial para se promover uma cidadania autêntica.

Nos anos 40, em 1941 mais precisamente, Orson Welles realizou Citizen Kane. O filme tratava de uma biografia não autorizada do dono de um império jornalístico nos Estados Unidos na primeira metade do século XX, William Randolph Hearst. O filme, considerado uma obra-prima do cinema mundial, se desenrola como se tratasse de uma reportagem. Um jornalista decide investigar a vida do magnata Charles Foster Kane que, ao morrer, pronuncia como última palavra a enigmática "rosebud". No desenrolar da história, construída de forma inovadora quer em termos narrativos quer em termos visuais, inaugurando toda uma nova forma de se realizar filmes, somos apresentados ao cidadão Kane desde a sua tenra infância até aos seus dias de glória como magnata da indústria jornalística. São-nos dadas a conhecer as suas tentativas de usar os jornais como fonte de propaganda pessoal, e também como instrumento poderoso de chantagem para alcançar os seus objetivos. Para mim, o mais fascinante do filme é a forma magistral como somos envolvidos numa grande mentira: todos nós, público, ouvimos Kane a pronunciar "rosebud" antes de morrer. Mas ninguém, dentro da diegese ouviu o mesmo, ou seja, não seria possível que um jornalista soubesse que esta tinha sido a sua última palavra. O que torna, já à partida, o argumento do filme inválido. Mas o facto é que ninguém se dá conta deste pormenor porque a magia do cinema, e a mestria de Welles, torna-nos cúmplices do narrador e somos arrastados pelo desejo de desvendar este mistério, seguimos a trama do jornalista que nos leva, só a nós e nunca a ninguém da própria diegese, a descobrir o que significava a tal palavra, tão importante, ao ponto de ser a última que o magnata pronunciou.

Citizen Kane é uma obra de ficção e não uma peça jornalística, mas o princípio que rege o argumento, e que regeu sempre a obra do próprio Welles, é o mesmo que rege, de alguma maneira, o bom jornalismo - a busca incansável da verdade, por mais absurda que esta possa parecer. Mas, no filme, há também o espetáculo, a procura do entretenimento, que o jornalismo nunca deixou de lado porque é preciso, além de informar, vender, seja a notícia, seja o veículo que a divulga. Não nos esqueçamos também que o filme é feito em plena II Guerra Mundial, período em que jornalismo e propaganda se confundiram um pouco por todo o lado, ora a defender os princípios democráticos ora a exaltar os valores do nazifascismo.

Logo a seguir ao fim da II Guerra, começa outra guerra que é disputada com as armas dos meios de comunicação e legtima, de uma vez por todas, o epíteto de quarto poder dado ao jornalismo. Desde então muitas foram as teorias que tentaram perceber de que forma se criam, ou devem ser criados, os discursos jornalísticos e de que forma podem, ou são interpretados, os textos que não só narram os factos da História como participam, ativamente, da sua criação.

A contemporaneidade é marcada pela consciência aguda de que a História é feita daquilo que dela se conta e o jornalismo tem um papel fundamental na construção da realidade. $\mathrm{Na}$ era digital, as redes sociais ocupam o lugar que antes era pertença apenas dos media na difusão de factos e de informação. Os jornais, ou os antigos media, sofreram, e sofrem ainda, o impacto da perda de leitores/espetadores e tentam aos poucos adaptar-se às 
novas configurações da notícia e às novas formas de narrativa que daí advém. Para alguns é uma batalha perdida, as notícias circulam a uma velocidade incontrolável e os factos são pertença de todos sem que haja sequer tempo de verificá-los. Estamos na era das fake news ou daquilo a que alguns cinicamente denominam de pós-verdade.

Se na ficção podemos acompanhar uma história, como a do Citizen Kane, que parte de uma premissa não verificada, no espaço do real cabe, a cada um de nós, repensar o papel que o jornalismo assume nos dias que correm. Porque é muito fácil deixar-se enredar pela rapidez e eficiência com que os dados circulam e esquecer-se de que, sendo o jornalismo indubitavelmente uma forma de poder, este poder traz consigo uma grande responsabilidade, e talvez seja esse o papel do jornalismo na era digital: ajudar na reconstrução de um discurso mais credível, factual e verificável, do mundo real.

\section{BREVE SEMBLANZA DE LA AUTORA:}

Mirian Nogueira Tavares. Professora Associada da Universidade do Algarve. Com formação académica nas Ciências da Comunicação, Semiótica e Estudos Culturais (doutorou-se em Comunicação e Cultura Contemporâneas, na Universidade Federal da Bahia), tem desenvolvido o seu trabalho de investigação e de produção teórica, em domínios relacionados com o Cinema, a Literatura e outras Artes, bem como nas áreas de estética fílmica e artística.

Como professora da Universidade do Algarve, participou na elaboração do projeto de licenciatura em Artes Visuais, do mestrado e doutoramento em Comunicação, Cultura e Artes e do doutoramento em Média-Arte Digital. Atualmente é Coordenadora do CIAC (Centro de Investigação em Artes e Comunicação - http://www.ciac.pt

Ámbitos. Revista Internacional de Comunicación, n.40, edición de primavera, 2018. 